\title{
FUTBALL SZIMULÁCIÓ MEGVALÓSÍTÁSA FUZZY SZABÁLY INTERPOLÁCIÓ ALAPÚ FUZZY AUTOMATÁVAL
}

\author{
Tóth Alex \\ MSc hallgató, Miskolci Egyetem \\ Informatikai Intézet, Altalános Informatikai Intézeti Tanszék \\ 3515 Miskolc, Miskolc-Egyetemváros, e-mail: toth.alex@iit.uni-miskolc.hu \\ Vincze Dávid \\ egyetemi docens, Miskolci Egyetem \\ Informatikai Intézet, Általános Informatikai Intézeti Tanszék \\ 3515 Miskolc, Miskolc-Egyetemváros, e-mail: vincze.david@iit.uni-miskolc.hu
}

\begin{abstract}
Absztrakt
Jelen cikk egy fuzzy automatával vezérelt futball szimuláció modelljét mutatja be. A szimuláció ágenseinek (játékosainak) irányitása olyan fuzzy szabálybázisokkal történik, amelyekben csak a tényleges müködéshez szükséges, leglényegesebbnek vélt szabályok lettek definiálva. Az ilyen, ritka fuzzy szabálybázisokat a klasszikus fuzzy következtetö rendszerek, müködésükböl adódóan nem tudják alkalmazni. Ellenben, fuzzy szabály interpolációs (Fuzzy Rule Interpolation - FRI) módszer használatával az ágensek ritka fuzzy szabálybázisokkal is vezérelhetök. Ezen munka célja egy olyan modell konstruálása és bemutatása, amely a futball szimuláció vezérléséhez olyan tudásreprezentációt használ, amely emberek által is közvetlenül, könnyen értelmezhetö. Erre a célra kiválóan alkalmasak a ritka fuzzy szabálybázisok, önmagyarázó mivoltuknak köszönhetöen.
\end{abstract}

Kulcsszavak: fuzzy szabály interpoláció, viselkedés alapú irányitás, fuzzy irányitás, futball szimuláció

\section{Abstract}

This paper introduces the model of a fuzzy automaton controlled football simulation. The controlling of the agents (football players) of the simulation is realized by evaluating such fuzzy rule-bases, which contain only the most important rules able to make the system work (forming so called sparse rulebases). Classical fuzzy inference methods require complete rule-bases by design and cannot handle this kind of sparse rule-bases. However, by apply-ing fuzzy rule interpolation (FRI), using sparse rulebases to control the agents becomes possible. The goal of this work is to construct and present such a model, which employs a human-readable knowledge representation to control the football simulation. For this purpose the application of sparse fuzzy rule-bases is well suited, as these are self-describing by their nature.

Keywords: fuzzy rule interpolation, behavior based control, fuzzy control, football simulation

\section{Bevezetés}

Bátran állíthatjuk, hogy a futball az egyik legismertebb és legnépszerübb sport, ami rajongók sokaságát vonzza világszerte. A játékot két 11 főből álló csapat játssza (tíz mezőnyjátékos és egy kapus). A játék célja a gólszerzés és az a csapat nyer, amelyik több gólt szerez. A való élet mellett a futball a virtuális világban is nagy népszerüségnek örvend. Rengeteg játék, szimulátor, eredmény előrejelző, 
stb. készült már, melyek különböző megközelítéssekkel próbálják modellezni és implementálni a játékot illetve egyes részeit.

Egyik népszerü és érdekes területe a futball szimulációk alkalmazásának a robot futball, ami kapcsán versenyeket is rendeznek. Ilyen verseny a széles körben ismert és elismert RoboCup, ahol a különbözőképpen a játékra programozott robot csapatok robot futballban versenyeznek egymással, ugyanis a RoboCup a következőt tüzte ki céljául: „A 21. század közepére egy teljesen autonóm, humanoid robot futballcsapatnak képesnek kell lennie, a FIFA hivatalos szabályait betartva, legyözni az aktuális világbajnok emberi futballcsapatot." [8]. Ennek eléréséhez természetesen még rengeteg kutatási munka várat magára. Ellenben számos különböző megoldás született már a RoboCup versenyre, a legkülönfélébb mesterséges intelligencia módszerek alkalmazásával (lásd többek között: [14], [15], [20], [23], [24] és [25]).

A [14]-ben bemutatott megoldás például megerősítéses tanulást alkalmaz, hogy feltárja azokat az alapvető képességeket, amelyek ahhoz szükségesek, hogy egy ágens megszerezze a labdát. Egy másik megközelítés [15], szintén megerősítéses tanulást, a Q-learning egy változatát használja. Itt a cél annak a tudásnak a feltérképezése, hogy mikor melyik akciót (passzolás, elrúgás, cselezés) érdemes az ágensnek végrehajtania a korábban felhalmozott tapasztalatok figyelembe véve. A [20]-ban bemutatott variáció Fuzzy Q-learning segítségével térképezi fel az ágens támadási viselkedését (hasonlóan a [15]ben leírt akciókat), az alapján, hogy az ellenfél ágensei, illetve kapuja milyen távolságra és milyen irányban találhatóak az adott helyzetben. Ellentétben ezekkel a megoldásokkal, melyek a futball szimulációban a támadáshoz szükséges viselkedést írják le, az [23]-ban bemutatott munka a védekezésre fekteti a hangsúlyt. Itt a védekezési stratégiák és a defenzív játékstílus a cél, olyan helyzetek kezelése ahol a védekező ágensnek aktívan be kell avatkoznia a labdát vezető támadó ágenssel szemben, hogy meghiúsítsa az ellenfél csapat támadását. Olyan hierarchikus, hibrid fuzzycrisp módszereket mutatnak be a szerzők a [24]-ben, amelyek alkalmasak lehetnek az ellenfél csapat stratégiájának felismerésére, és ez alapján meghatározni, hogy melyik ágensnek hol lehetne a legjobb felvehető pozíciója a pályán.

Ebben a cikkben egy másfajta megközelítést mutatunk be: az ágensek viselkedését fuzzy szabályokkal, szakértő-rendszer szerüen írjuk le, de olyan módón, hogy kizárólag a fontos szabályokat definiáljuk. Ez klasszikus fuzzy irányítási rendszerekben nem lehetséges, mivel ott mindig szükség van egy teljes, ún. fedő szabálybázisra. A fuzzy szabály interpolációs módszerek erre a problémára adnak lehetséges megoldást, mivel ezek használatával lehetőség nyílik szándékosan hiányos, ún. ritka szabálybázisokkal is következtetéseket nyerni és felhasználni azokat az ágensek irányítására.

A következő fejezetekben bemutatásra kerülnek az alkalmazott módszerek, illetve a szimulációt múködtető tudásbázis alkotóelemei és a kapcsolódó keretrendszer. Ezek az eredmények viselkedés komponensként felhasználhatóak a későbbiekben, akár a RoboCup követelményeinek megfelelő ágensek vezérlésére.

\section{A szimuláció modellje}

A szimuláció modelljének megvalósítása a klasszikus viselkedés alapú irányítás [17] felépítést követi. Egy ilyen rendszerben a tényleges (kimeneti) viselkedést adhatja egyrészt az éppen az adott szituációra legjobban illeszkedő, előre definiált viselkedés komponens, vagy a legmegfelelőbbnek tünő viselkedés komponensek összegzése (fúziója). A futball szimulációban a játékosok az ágensek, és ezeknek a viselkedését írják le a konstruált szabálybázisok. A viselkedések több komponensből is állhatnak, amelyeknek a szükségességét a szabálybázisok kiértékelése határozza meg. Ezekből a szükségesség érté- 
kekből (súlyokból) pedig az adott viselkedések fúziójával áll elő a végrehajtandó tényleges akció. Az itt bemutatott szimuláció modelljét, azaz a viselkedés elemeket ritka fuzzy szabálybázisok írják le.

A fuzzy logika alapú irányítási rendszerek előnye, hogy a müködtető szabálybázis tudásreprezentációja önmagyarázó. Ez a fuzzy szabályok formátumából adódik, amelyek nyelvi változókat (pl. kicsi, nagy, közel, távol, lassú, gyors, stb.) használnak az összefüggések leírásához. Ezek a nyelvi változók HA-AKKOR kapcsolatokkal vannak szabályokká formálva, lásd például (1):

$$
\text { HA labda_távolsága }=k o ̈ z e l \text { ÉS ellenfél_távolsága }=k o ̈ z e l ~ \mathbf{A K K O R ~ f u t a ́ s ~}=\text { gyors }
$$

A fuzzy szabálybázisokat pedig ilyen jellegü fuzzy szabályok alkotják. A szabálybázisokat pedig különböző fuzzy következtető módszerekkel lehet kiértékelni. Ilyen klasszikus fuzzy következtető módszer például a nagyon gyakran alkalmazott nulladrendủ Takagi-Sugeno módszer [19], mivel ennek kimenete nem fuzzy halmaz, hanem közvetlenül felhasználható, ún. éles következtetést ad. A klasszikus fuzzy szabályzórendszerek müködéséhez olyan szabálybázisokra van szükség, amikben minden lehetséges esethez található valamilyen mértékben illeszkedő szabály (fedő szabálybázis). Ezek a teljes szabálybázisok így sok olyan szabályt tartalmazhatnak, amelyek hasznos információt valójában nem hordoznak. A redundáns szabályokat ellenben nem lehet elhagyni, mivel a rendszer müködésképtelenné válna, így már néhány nyelvi változó esetén is elvesztheti a szabálybázis az olvashatóságát, hiába a fuzzy szabály önmagyarázó mivolta.

Erre a problémára kínálnak megoldást a fuzzy szabály interpolációs módszerek, amelyek lehetővé teszik a következtető rendszerek müködését, azokban az esetekben is, amikor a szabálybázisok nem fedő szabálybázisok. FRI módszerek és gépi tanulás együttes alkalmazásával lehetőség nyílik hatékony tudáskinyerésre is (részletekért lásd [29], [30], [21] és [31]), így kiaknázva a fuzzy szabályokkal leírt rendszerek előnyeit.

\subsection{Fuzzy szabály interpoláció}

A fuzzy szabály interpolációs (Fuzzy Rule Interpolation - FRI) módszerek lényege, hogy olyan esetekben is tudnak következtetést hozni, amikor az adott megfigyelésre (bemenet) nincs megadva szabály a szabálybázisban. Ezt a következtetést a többi, más esetekre megadott szabályok felhasználásával számítják ki. Számos különböző fajta fuzzy szabály interpolációs módszert fejlesztettek ki az elmúlt évtizedekben, a különböző FRI módszerekről részletes áttekintést nyújt [1], továbbá gyakorlati FRI alapú alkalmazásokat mutat be [4], [5], [6], [13], [22] és [26].

Ezen FRI módszerek egyike a FIVE FRI, mely a szimuláció müködtetéséhez felhasználásra került. A FIVE (Fuzzy rule Interpolation based on Vague Environment - bizonytalan környezet alapú fuzzy szabály interpoláció) egy alkalmazás orientált FRI módszer (részleteket lásd [10] és [11]). Ez a módszer egy alacsony számításigényü és közvetlenül használható egyértékü (crisp - éles) következményt ad, amely gyakorlati alkalmazás esetén (mint ez a futball szimulációs modell) elönyös, mivel nincs szükség defuzzifikációs lépésre.

A módszer alapja onnan ered, hogy a legtöbb szabályzástechnikai alkalmazás konkrét megfigyelésekkel (observation) dolgozik és nem igényel a kimeneten fuzzy következtetést. A bizonytalan környezet (Vague Environment - VE) [9] ötletének felhasználásával a FIVE egyértékü halmazok és fuzzy partíciók távolságát nem-fuzzy távolságokká alakítja, így tetszőleges klasszikus interpolációs módszert képes fuzzy szabály interpolációként alkalmazni. A bizonytalan környezet koncepciója az elemek hasonlóságán vagy megkülönböztethetetlenségén alapul. Két elem megkülönböztethetetlenségének a 
mértéke ebben a bizonytalan környezetben a súlyozott távolságuk függvényében változik. Ez utóbbi súlytényezőket nevezik skálafüggvényeknek. Amennyiben egy fuzzy partíciónak létezik skálafüggvénye (vagy ennek egy közelítése, lásd [10] és [11]), akkor a fuzzy partíciót alkotó fuzzy halmazok a bizonytalan környezetben pontokként jellemezhetőek. Ezáltal bármilyen klasszikus interpolációs vagy extrapolációs eljárás egyszerúen fuzzy szabály interpolációs eljárássá alakítható [10], [11]. A FIVE a Shepard operátor (lásd [18]) alapú interpolációs módszert használja, mivel többdimenziós esetekben is egyszerüen alkalmazható.

A FIVE és számos más FRI módszer implementációjának forráskódja több programnyelven is bárki számára ingyenesen hozzáférhető az FRI Toolbox részeként [3], [7].

\subsection{A szimuláció tudásbázisa}

Az előbbiekben leírtakat figyelembe véve, így a futball szimulációs modell alapja egy fuzzy szabály interpoláció alapú fuzzy automata [13] [2] [12], ami valós időben képes meghatározni a különböző viselkedés komponensek szükségességének mértékét (rendszer állapotának becslése, ahol az állapotok a különböző viselkedés komponensek szükségességeit jelentik). Másrészt meghatározza, hogy hogyan történjen a viselkedés komponensek összegzése. A következőekben kerülnek bemutatásra a szimulációban használt viselkedéskomponenseket leíró fuzzy nyelvi változók és szabálybázisok.

Négy különböző nyelvi változót használ a szimuláció a fuzzy szabályokban, melyek a távolság, labdabirtoklás, eredmény, és egy kétértékü nyelvi változó, amely az igaz és hamis logikai értékeket reprezentálja. A normalizált távolságokat a nulla távolság, közeli, közepes távolság, távoli, nagyon távoli és maximális távolság fuzzy halmazok írják le (lásd az 1. ábrán). Ezeknél a halmazoknál fontos, hogy legyen közöttük átfedés, annak érdekében, hogy folyamatos átmenetek legyenek a szimulációban és ne fordulhassanak elő ugrásszerü változások a konklúzióban a távolság változása okán.

A labdabirtoklás nyelvi változó összesen három különbözö értéket vehet fel. Ennek a nyelvi változónak a segítségével jelölhető, hogy melyik csapatnál van a labda, így értéke egy ellenfél játékost vagy egy csapattársat jelölhet, vagy éppen azt, hogy senkinél nincs a labda. Ezek háromszög alakú tagsági függvénnyel rendelkeznek, mely háromszögek oldalainak meredeksége mindkét oldalon végtelenként definiált. A nagy meredekség biztosítja, hogy a halmazok között ne legyen átfedés, így egyértelmüen meghatározható, hogy melyik csapat birtokolja a labdát. Vannak más olyan tényezők is, amelyek leírhatóak lennének a klasszikus logika segítségével, azonban ezeket itt fuzzy halmazokkal kell lefedni. A labdabirtokláshoz hasonlóan az igaz és hamis logikai értékeket reprezentáló fuzzy halmazok közötti átfedést is el kell kerülni a nagy meredekségek alkalmazásával.

Végül, az eredmény nyelvi változónak a konklúziók leírásában van szerepe. Ez, a távolsághoz hasonlóan, a $[0 ; 1]$ intervallumon bármilyen értéket felvehet, amely érték azt jelenti, hogy egy adott akciót mekkora mértékben kell végrehajtani.

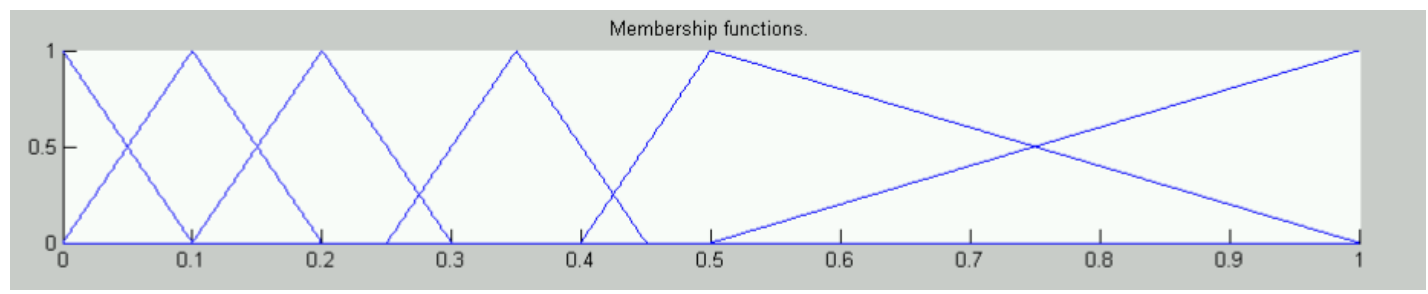

1. ábra. A távolság nyelvi változóhoz tartozó tagsági függvények. 


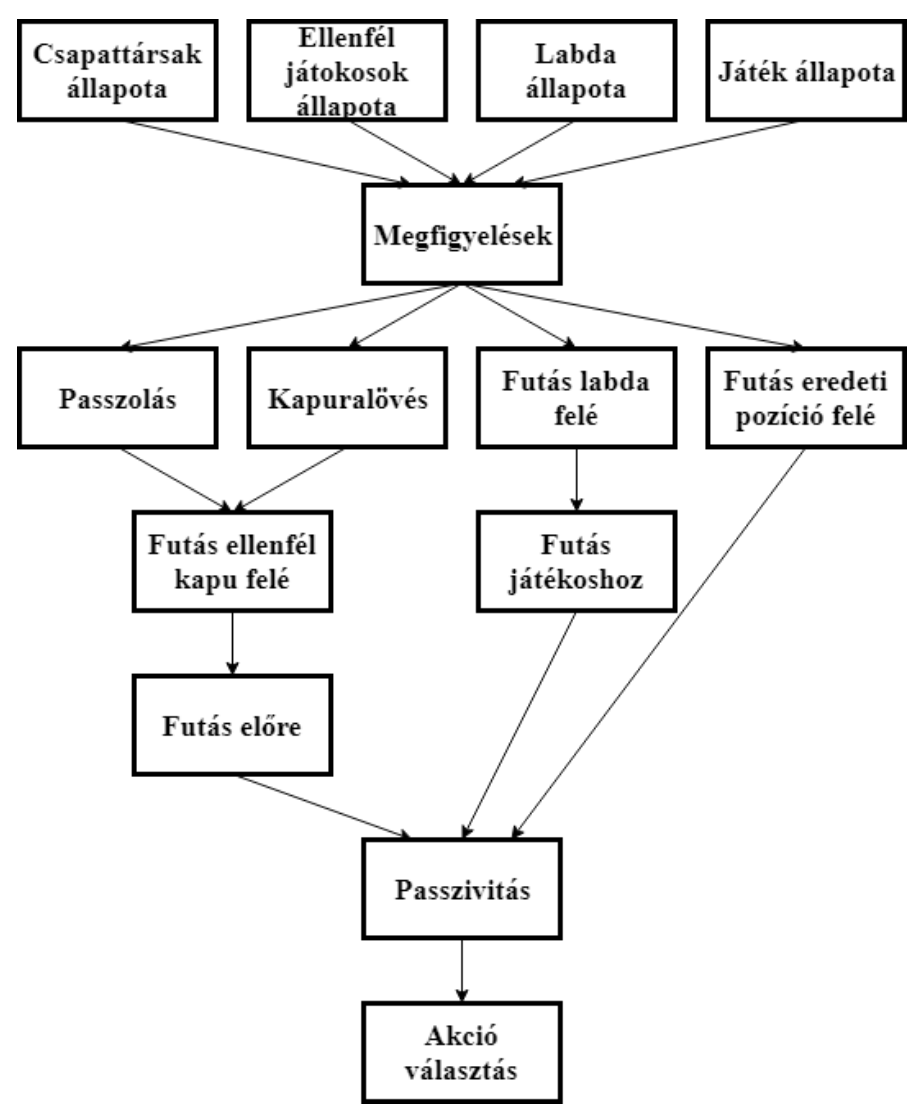

2. ábra. A futball szimuláció modelljének felépitése

Az ágensek vezérlését ritka fuzzy szabálybázisok írják le, melyek a fentebb bemutatott nyelvi változókat használják. Minden szabálybázis rendelkezik egy kimenettel és legalább egy bemenettel. A kimenetük a kapcsolódó viselkedés komponens súly értéke, mely megmutatja, hogy egy adott akciót milyen mértékben kell végrehajtani. Egy szabálybázis kimenete felhasználható egy másik szabálybázis bemeneteként, így a szabálybázisok között kialakítható egyfajta hierarchia. A modell szabálybázisai közötti kapcsolatok a 2. ábrán követhetöek nyomon.

Az ágensek, azaz a játékosok a szimuláció során négy fö viselkedésforma közül választhatnak minden egyes iterációban, melyek a következőek: kapura lövés, passzolás, mozgás, és passzivitás. Az ágensek mozgását valójában több viselkedéskomponens kombinációja együttesen határozza meg, ezek a következőek: 1 . futás az eredeti pozíció felé, 2. futás a labda felé, 3 . futás más játékoshoz, 4. futás az ellenfél kapuja felé, illetve 5. futás elöre. A tényleges mozgásvektor ezen öt viselkedés komponens fúziójából adódik. A másik három viselkedésforma közvetlenül kiértékelhető.

A játékosok a pályán betöltött szerepüktől függően különbözöképpen reagálnak a bemenetekre az egyes állapotokban. Az egyszerüséget szem előtt tartva, négy különböző játekos szerepkör lett meghatározva a szimulációban: kapus, hátvéd, középpályás és csatár. Minden szerepkör saját szabálybázis halmazzal rendelkezik, így adódik, hogy a szimulációban összesen 28 fuzzy szabálybázis tartozik ehhez a négy szerepkörhöz, valamint a passzivitás akció szabálybázisa, amit szerepkörtől függetlenül közösen használnak az ágensek. 
1. táblázat. A kapura lövés akciót leiró szabálybázis

\begin{tabular}{|c|c|c|c|c|c|}
\hline$\#$ & A1 & A2 & A3 & A4 & C \\
\hline 1 & HAMIS & BÁRMI & BÁRMI & BÁRMI & NE_TEDD \\
\hline 2 & BÁRMI & HAMIS & BÁRMI & BÁRMI & NE_TEDD \\
\hline 3 & BÁRMI & BÁRMI & TÁVOLSÁG_MESSZE & BÁRMI & NE_TEDD \\
\hline 4 & BÁRMI & BÁRMI & BÁRMI & IGAZ & NE_TEDD \\
\hline 5 & IGAZ & IGAZ & TÁVOLSÁG_KÖZEL & HAMIS & TEDD \\
\hline
\end{tabular}

Tekintve, hogy a játék célja a gólszerzés, a kapura lövés akció és a hozzá tartozó szabálybázisok a legfontosabbak a szimulációban. Ezeknek a szabálybázisokra négy bemeneti tényezőre van szükségük a döntéshozatalhoz, melyek a következők: 1. az éppen vizsgált játékosnál van-e a labda (A1), 2. látható-e az ellenfél kapuja a vizsgált játékos számára (A2), 3. milyen távol van az ellenfél kapu a vizsgált játékostól (A3), valamint 4. elakadt-e a labda valahol a pályán (A4). Ezen tényezők ismeretében és a vonatkozó szabálybázis alapján elóállítható egy kimeneti érték (C), amely azt jelzi, hogy a játékosnak kapura kell-e lőnie a labdát, vagy sem. A csatárok által használt kapura lövés szabálybázis szabályait az 1. táblázat írja le. Az első szabály biztosítja, hogy csak a labdát birtokló játékos tudja ezt az akciót végrehajtani. A második és harmadik szabály jelentése, hogy ha messze van a kapu, vagy valamilyen akadály lenne a labda útjában, akkor ne legyen kapura lövés. Az utolsó szabály azt jelenti, hogy csak a labdát birtokló játékos rúghat kapura, olyankor, ha közel van a kapuhoz és akadály sincs előtte.

Továbbá a kapura lövés mellett van még egy fontos akció, a passzolás, melyet csak a labdát birtokló játékos képes végrehajtani. A kapura lövéshez, és minden más akcióhoz tartozó szabálybázishoz hasonlóan a passzolás szabályai „kizárók/exkluzívak”, olyan értelemben, hogy amennyiben illeszkednek a bemenetre, akkor az akciót nem szabad végrehajtani. A passzoláshoz kapcsolódó szabálybázisok kimenetének feldolgozása valamelyest eltér más szabálybázisokétól, mivel itt minden vizsgált játékosra tíz különböző eredmény adódik, melyek közül egyet kell kiválasztani. Kézenfekvő lenne mindig azt a célpontot választani, amelyhez a legnagyobb konklúzió érték (súly) tartozik, azonban annak érdekében, hogy a szimuláció életszerübb legyen, a passzolás célpontja a három legmagasabb konklúzióval rendelkező közül véletlenszerüen kerül kiválasztásra.

Ahogy már említésre került, a mozgás akció öt különböző komponensből tevődik össze. Ezekből az egyik komponens a „futás az eredeti pozíció felé”, amely garantálja, hogy a játékosok nem fognak a pálya tetszőleges, akár az adott szerepkörben értelmetlennek tủnő, pontjára menni, hanem a kezdeti pozíciójuk közelében próbálnak mozogni a játék szempontjából abszurd helyzetek elkerülése érdekében. Az ehhez kapcsolódó szabálybázisoknak csak néhány bemeneti tényezőre van szüksége: 1. a vizsgált játékosnál van-e a labda, 2. milyen messze van a játékos a kezdeti pozíciójától, illetve 3. elakadt-e a labda.

Egy másik mozgással kapcsolatos viselkedés komponens a „futás a labda felé”. Ez is kardinális része a szimulációnak, és magának a játéknak is, mivel bizonyos akciókat csak a labdát birtokló játékos képes elvégezni, így más játékosoknak meg kell próbálniuk azt leszerelni, hogy a labdához jussanak. A bemutatásra kerülők közül az ide kapcsolódó szabálybázisok az elsők, ahol megjelenik a labdabirtoklás nyelvi változó, mivel itt nem elég azt meghatározni, hogy az éppen vizsgált játékosnál van-e labda, azt is tudni kell, hogy csapattárs, vagy ellenfél birtokolja azt, vagy éppen senkinél sincs.

A labdarúgásban az ún. emberfogás lényege, hogy egy ellenfél játékos közelében maradva megakadályozzák, hogy az labdát szerezzen vagy a kapu közelében gólhelyzetbe kerüljön. A „futás más játékoshoz" és az emberfogás elengedhetetlen a védekező játékosok számára, ez jelentősen megkönynyíti számukra a labdaszerzést. 
2. táblázat. Az elörefutás akciót leiró szabálybázis

\begin{tabular}{|c|c|c|c|c|c|c|c|}
\hline$\#$ & A1 & A2 & A3 & A4 & A5 & A6 & C \\
\hline 1 & IGAZ & BÁRMI & BÁRMI & BÁRMI & BÁRMI & BÁRMI & NE_TEDD \\
\hline 2 & BÁRMI & TEDD & BÁRMI & BÁRMI & BÁRMI & BÁRMI & NE_TEDD \\
\hline 3 & BÁRMI & BÁRMI & TEDD & BÁRMI & BÁRMI & BÁRMI & NE_TEDD \\
\hline 4 & BÁRMI & BÁRMI & BÁRMI & TEDD & BÁRMI & BÁRMI & NE_TEDD \\
\hline 5 & BÁRMI & BÁRMI & BÁRMI & BÁRMI & HAMIS & BÁRMI & NE_TEDD \\
\hline 6 & BÁRMI & BÁRMI & BÁRMI & BÁRMI & BÁRMI & IGAZ & NE_TEDD \\
\hline 7 & HAMIS & NE_TEDD & NE_TEDD & NE_TEDD & IGAZ & HAMIS & TEDD \\
\hline
\end{tabular}

Amikor egy játékos megszerzi a labdát, főleg ha támadó játékosról van szó, meg kell próbálnia jobb helyzetbe kerülnie a gólszerzéshez, vagy segédkezni egy támadás előkészítésében, hogy a csapattársak gólt szerezhessenek. Az ide kapcsolódó szabálybázisok felelősek annak meghatározásáért, hogy a játékosnak kell-e mozognia az ellenfél kapujának irányába, vagy sem. Amíg a labdát birtokló játékos számára fontos lehet, hogy az ellenfél kapujának közelébe férkőzzön, más játékosoknak egyes esetekben célszerübb lehet tartani a pozíciójukat egy kissé előrébb húzódva a pályán. Utóbbit elősegítő szabálybázist mutat a 2 . táblázat, aminek három bemeneti tényezője egy másik, korábban kiértékelt szabálybázis kimenete (állapot). Az ezekhez kapcsolódó szabályok (2-4. szabály a 2. táblázatban), azt írják le, hogy ha valamelyik akciót végre kell hajtani (például kapura lőni vagy passzolni), akkor ne válasszák az előrefutás mozgást. Az előrefutásnál figyelembe vett tényezők: rögzített helyzetet kell-e végrehajtani (A1), kapura lövés (A2), passzolás (A3) és futás az ellenfél kapuja felé (A4) szabálybázisok kimenete, az ellenfél térfelén van-e a labda (A5) és, hogy elakadt-e valahol a labda (A6).

A tényleges mozgásvektor a fentebb említett öt mozgáskomponens kombinációjaként adódik. Mindegyik komponenshez tartozik egy kimeneti érték, amely a megfigyelések alapján előállítható. Ahhoz, hogy a szimuláció során a játékosok mozgása folyamatos legyen, hirtelen irányváltások nélkül, a kapott konklúziók súlyokként vannak felhasználva a mozgásvektor kiszámításánál. Valójában minden szabálybázis kiértékelődik, így előállnak súlyértékek minden iterációban a szimuláció során. A mozgásvektor a (2) alapján kerül kiszámításra:

$$
\text { direction }_{\text {final }}=\sum_{x \in A} \text { direction }_{x} \cdot w_{x}
$$

ahol direction final $_{\text {a }}$ tényleges mozgásvektor, $A$ a mozgáskomponensek halmaza, $w_{x}$ pedig az $x$ mozgáskomponenshez tartozó szabálybázis által előállított konklúzió. Így, a mozgás iránya a kapott mozgásvektor, az értéke pedig a kapcsolódó szabálybázisok kimenetei közül a legmagasabb lesz.

A passzivitás az egyetlen olyan akció a szimulációban, amelyhez csupán egy szabálybázis tartozik és minden ágens használ. Ez a szabálybázis bemenetként az összes többi kimenetét várja, és ez alapján eldönti, kell-e tennie valamit a vizsgált játékosnak. Lényegében ennek a szabálybázisnak a feladata csak annyi, hogy olyan esetekben, amikor minden más szabálybázis alacsony konklúziót adott, a legkevésbé rossz akció választása helyett várakoztassa a játékost, addig amíg nem adódik valami olyan akció, amit érdemes végrehajtani. Az ide tartozó összesen nyolc szabály nagyon egyszerü, azt írják le, hogy ha bármely más akcióra az lett a konklúzió, hogy érdemes végrehajtani, akkor ne válassza, egyébként pedig válassza a passzivitást a játékos. Ha minden lehetséges akció kiértékelésre került, négy különböző eredmény áll rendelkezésre, melyek az egyes akciókhoz tartozó konklúzió értékét és más adatokat, mint például egy passz címzettje, tartalmazhatnak. A kapott eredmények alapján minden játékos a legmagasabb konklúzióval rendelkező akciót hajtja végre. 


\subsection{A müködtető keretrendszer}

A szimuláció számítási modelljének tényleges használatához szükséges egy keretrendszer, aminek feladata elsősorban a vizualizáció, a környezet szimulációja (játékosok, pálya, labda stb.) és a modell iterációról iterációra való kiértékelése.

A játékosok esetén fontos tényező a játékos pályán elfoglalt aktuális pozíciója és mozgásának iránya. A játékosok kezdeti pozíciójának, valamint szerepkörének fontos szerepe van a viselkedés meghatározásában, ugyanis a szerepkörtől függ, hogy mely szabálybázisok kimenetére lesz szükség a döntéshozásoknál. A már említettek mellett fontos tényezö az is, hogy a játékos melyik csapathoz tartozik. Ezeken kívül vannak olyan tulajdonságai is a játékosoknak, amelyeknek inkább csak a látvány szempontjából van jelentőségük a szimulációban, de némelyik akár közvetve felhasználható egyes szabálybázisokban, ilyenek például a játékos gyorsasága, el van-e éppen tiltva a játékos stb.

Jelentős tényező a labda mozgása és az azt birtokló játékos megkülönböztetése, amely befolyásolja az ágensek viselkedését és hatással van választott akciókra. A szimuláció során minden iterációban választani kell egy játékosokat, aki a labdát birtokolhatja, ez a labda közelében lévő játékosok közül véletlenszerüen történik. Normális esetben a labdát birtokló játékos kijelölését követően egyszerüen folytatódik a szimuláció, más esetben, például, ha szabálytalanság történt, akkor rögzített helyzetből hozhatja játékba a labdát a sértett csapat egy játékosa. A szimuláció során a labda tulajdonságai közül a legfontosabb a labda pozíciója, illetve, hogy melyik csapat birtokolja azt. Azonban vannak olyanok tényezők is (a játékosokhoz hasonlóan), amelyeknek inkább csak a látványban van szerepük, de közvetve vagy akár közvetlenül a szimulációt is befolyásolhatják, mint például, hogy elakadt-e valahol a pályán a labda, milyen erős legyen a súrlódás, stb.

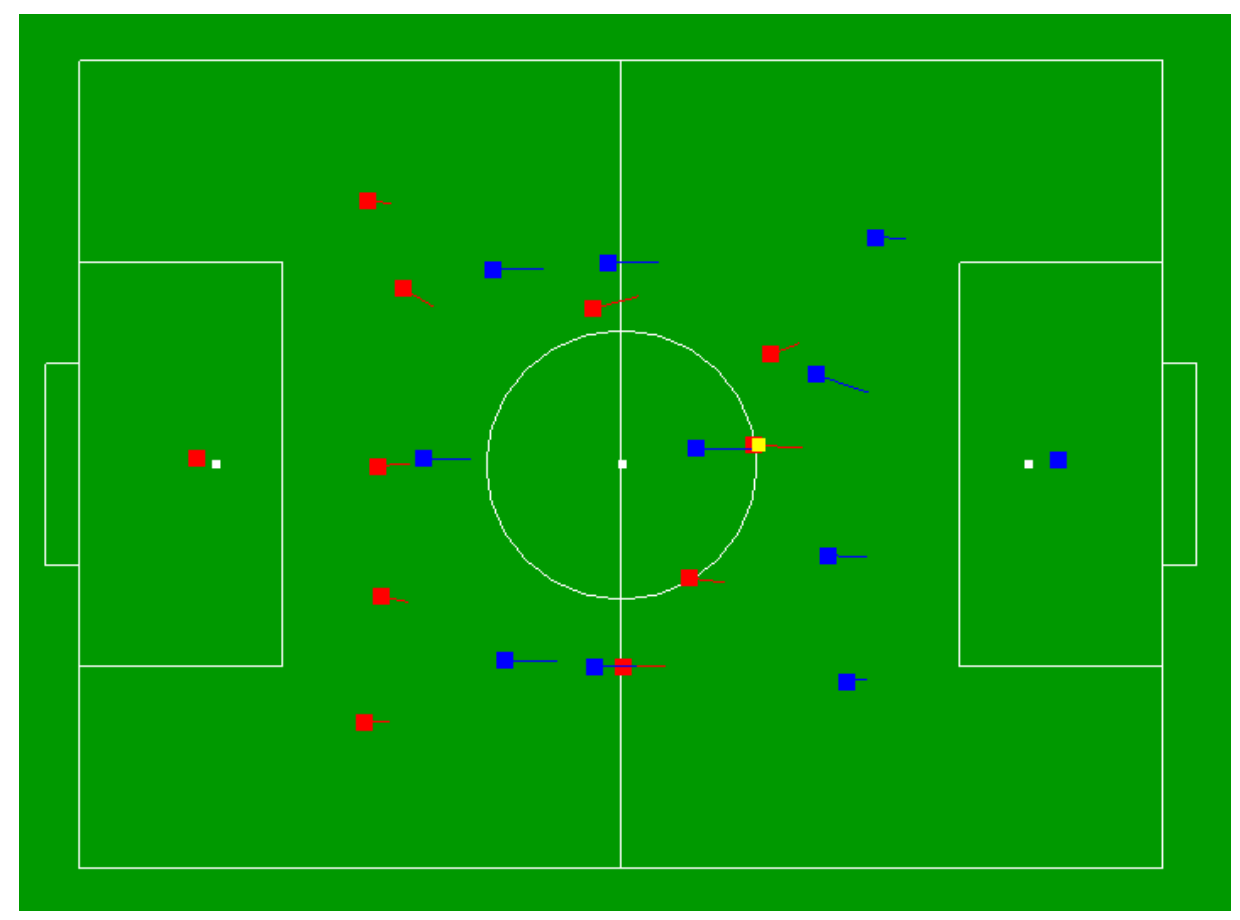

3. ábra. A futball szimuláció modell keretrendszere müködés közben 
Maguknak a csapatoknak a modellezésére egyszerüsítésképpen volt szükség, mivel így egy külön rétegben kezelhetők az egy csapatba tartozó játékosok, a különböző felállások stb. A szimuláció folyamatában ez csak közvetve játszik szerepet, például olyan esetekben, ha azt kell eldönteni, hogy melyik csapat játékosa birtokolja a labdát.

Amint az előző alfejezetben ismertetésre került, a végrehajtható akciók a kapura lövés, passzolás, mozgás és passzivitás, melyeket különböző tényezők befolyásolhatnak. Ezeknek a megjelenítése és a labda mozgás kiszámítása a vizualizációs keretrendszer feladata.

A 3. ábrán egy, a szimuláció során készült pillanatkép látható. Sárga színnel van jelölve a labda, pirossal a hazai-, kékkel pedig a vendég csapat játékosai. A piros és kék vonalak az egyes játékosok aktuálisan végrehajtandó mozgásvektorait mutatják.

\section{3. Összefoglalás}

A bemutatott fuzzy automata alapú számítási modell a hozzá tartozó keretrendszerrel képes valós időben egy futball szimuláció ágenseit (játékosiat) megfelelően, életszerủen vezérelni. A játékosok viselkedéselemeit ritka fuzzy szabálybázisok írják le, melyek előnye, hogy kizárólag a ténylegesen müködtető, fontos szabályokat tartalmazzák, amelyek ember által is közvetlenül értelmezhető formátumúak (ellentétben a manapság népszerü deep-learning módszerekkel, ahol a müködtető tudás rejtve marad).

A FIVE FRI módszer használatával elegendő volt csupán néhány szabályt megadni szabálybázisonként, mivel a többi esetre az interpolációval adódik felhasználható kimenet. FRI nélkül minden lehetséges esetet le kellene fedni szabályokkal, így a bemenetek számától és azok lehetséges értékeitől függően rengeteg szabályra lett volna szükség. Például, a passzivitással kapcsolatos szabálybázisnak hét bemeneti tényezője van, melyek mindegyike két különböző értéket vehet fel, „csináld” vagy „,ne csináld”, így a jelenlegi 8 helyett 128 szabályt kellene tartalmaznia. A teljes számítási modellt tekintve, FRI használata nélkül a 29 szabálybázisnak összesen 5536 szabályt kellene tartalmaznia a jelenlegi 176 helyett. Ez jelentősen csökkenti a rendszer komplexitását, ezáltal növeli a tudásreprezentáció olvashatóságát.

Számos további kutatási lehetőséget rejt magában az eddig elkészült munka. Többek között érdemes lehet a viselkedéselemek egységes, szabványosított viselkedés-leírónyelven [16] való implementálása. Másfelől az elkészült számítási modell jó alapot szolgáltathat automatikus tudáskinyeréshez [31], így ezt a modellt referenciaként felhasználva, fuzzy szabály interpoláció alapú megerősítéses tanulási módszerrel ki lehet nyerni (lásd [27], [28], [29], [21] és [30]) a múködtető szabálybázist. Ezt a kinyert tudásbázist összehasonlítva az eredetivel, esetleges új összefüggésekre derülhetne fény.

További fejlesztést és tesztelést követően a kifejlesztett modell alkalmas lehet arra, hogy valós robotok viselkedését irányítsa a RoboCup szabályainak megfelelően.

\section{Köszönetnyilvánítás}

A cikkben ismertetett kutató munka az EFOP-3.6.1-16-2016-00011 jelü „Fiatalodó és Megújuló Egyetem - Innovatív Tudásváros - a Miskolci Egyetem intelligens szakosodást szolgáló intézményi fejlesztése" projekt részeként - a Széchenyi 2020 keretében - az Európai Unió támogatásával, az Európai Szociális Alap társfinanszírozásával valósul meg. 


\section{Irodalom}

[1] Baranyi, P., Kóczy, L. T., Gedeon, T. D.: A Generalized Concept for Fuzzy Rule Interpolation, IEEE Trans. on Fuzzy Systems, vol. 12, No. 6, 2004, pp. 820-837. https://doi.org/10.1109/TFUZZ.2004.836085

[2] Doostfatemeh, M., Kremer, S. C.: New directions in fuzzy automata, International Journal of Approximate Reasoning 38, 2005, pp. 175-214. https://doi.org/10.1016/j.ijar.2004.08.001

[3] Johanyák, Zs. Cs., Tikk, D., Kovács, Sz., Wong, K. W.: Fuzzy Rule Interpolation Matlab Toolbox - FRI Toolbox, Proc. of the IEEE World Congress on Computational Intelligence (WCCI'06), 15th Int. Conf. on Fuzzy Systems (FUZZ-IEEE'06), July 16-21, Vancouver, BC, Canada, Omnipress. ISBN 0-7803-9489-5, 2006, pp. 1427-1433.

[4] Johanyák, Z. C.: Survey on Five Fuzzy Inference-Based Student Evaluation Methods, in Studies in Computational Intelligence, 2010, Vol. 313, Computational Intelligence in Engineering, pp. 219-228. https://doi.org/10.1007/978-3-642-15220-7_18

[5] Johanyák, Z. C., Parthiban, R. , Sekaran, G.: Fuzzy modeling for an anaerobic tapered fluidized bed reactor, Scientific Bulletin of "Politehnica" University of Timisoara, Romania, Transactions on Automatic Control and Computer Science, vol. 52(66), no: 2, June 2007, pp.67-72.

[6] Johanyák, Z. C., Ádámné, M.A.: Fuzzy Modeling of the Relation between Components of Thermoplastic Composites and their Mechanical Properties, Proceedings of the 5th International Symposium on Applied Computational Intelligence and Informatics (SACI 2009), May 2829, 2009, Timisoara, Romania, pp. 481-486. https://doi.org/10.1109/SACI.2009.5136296

[7] Johanyák, Z. C.: Sparse Fuzzy Model Identification Matlab Toolbox - RuleMaker Toolbox, IEEE 6th International Conference on Computational Cybernetics, ICCC 2008, Stara Lesná Slovakia, pp. 69-74. https://doi.org/10.1109/ICCCYB.2008.4721381

[8] Kitano, H., Asada, M.: RoboCup Humanoid Challenge: That's One Small Step for a Robot, One Giant Leap for Mankind, IEEE, Proceedings. 1998 IEEE/RSJ International Conference on Intelligent Robots and Systems. Innovations in Theory, Practice and Applications (Cat. No.98CH36190), 1998.

[9] Klawonn, F.: Fuzzy Sets and Vague Environments, Fuzzy Sets and Systems, 66, 1994, pp. 207-221. https://doi.org/10.1016/0165-0114(94)90311-5

[10] Kovács, Sz.: New Aspects of Interpolative Reasoning, Proc. of the 6th. International Conf. on Information Processing and Management of Uncertainty in Knowledge-Based Systems, Spain, 1996, pp. 477-482.

[11] Kovács, Sz., Kóczy, L.T.: The use of the concept of vague environment in approximate fuzzy reasoning, Fuzzy Set Theory and Applications, Tatra Mountains Mathematical Publications, Mathematical Institute Slovak Academy of Sciences, Bratislava, Slovak Republic, vol.12, 1997, pp. 169-181.

[12] Kovács, Sz: Interpolative Fuzzy Reasoning and Fuzzy Automaton in Adaptive System Applications, Proceedings of the IIZUKA2000, 6th International Conference on Soft Computing, October 1-4, Iizuka, Fukuoka, Japan, 2000, pp. 777-784.

[13] Kovács, Sz., Vincze, D., Gácsi, M., Miklósi, Á., Korondi, P.: Interpolation based Fuzzy Automaton for Human-Robot Interaction, Preprints of the 9th International Symposium on Robot Control (SYROCO'09), The International Federation of Automatic Control (IFAC), Nagaragawa Convention Center, Gifu, Japan, September 9-12, 2009, pp. 451-456.

[14] Sarje, A., Chawre, A., Nair, S. B.: Reinforcement learning of player agents in RoboCup Soccer 
simulation, IEEE, Fourth International Conference on Hybrid Intelligent Systems (HIS'04), 2004.

[15] Neri, J. R. F., Zatelli, M. R., d. Santos, C. H. F., Fabro, J. A.: A Proposal of QLearning to Control the Attack of a 2D Robot Soccer Simulation Team, IEEE, 2012 Brazilian Robotics Symposium and Latin American Robotics Symposium, 2012. https://doi.org/10.1109/SBRLARS.2012.35

[16] Piller, I., Vincze, D., Kovács, Sz.: Declarative Language for Behaviour Description. Emergent Trends in Robotics and Intelligent Systems: Advances in Intelligent Systems and Computing, Vol 316. Springer, Cham, 2015, pp. 103-112. https://doi.org/10.1007/978-3-319-10783-7_11

[17] Pirjanian, P.: Behavior Coordination Mechanisms - State-of-the-art, Tech-report IRIS-99-375, Institute for Robotics and Intelligent Systems, School of Engineering, University of Southern California, October (1999)

[18] Shepard, D.: A two dimensional interpolation function for irregularly spaced data, Proc. 23rd ACM Internat. Conf., 1968, pp. 517-524. https://doi.org/10.1145/800186.810616

[19] Takagi, T., Sugeno, M.: Fuzzy identification of systems and its applications to modeling and control. IEEE Trans. on SMC, (15), 1985, pp. 116-132. https://doi.org/10.1109/TSMC.1985.6313399

[20] Takahashi, K., Ueda, H., Miyahara, T.: Agent learning in simulated soccer by fuzzy Q-learning, IEEE Region 10 Conference TENCON 2004.

[21] Tompa, T., Kovács, Sz.: Clustering-based fuzzy knowledgebase reduction in the FRIQlearning, Proceedings of the 15th International Symposium on Applied Machine Intelligence and Informatics (SAMI 2017), January 26-28, 2017, Herl'any, Slovakia, pp. 197-200. https://doi.org/10.1109/SAMI.2017.7880302

[22] Tompa, T., Vincze, D., Kovács, Sz.: The Pong game implementation with the FRIQ-learning reinforcement learning algorithm, in Proceedings of the 16th International Carpathian Control Conference (ICCC), Szilvásvárad, Hungary, May 27-30, 2015, pp. 542-547.

[23] Gabel, T., Riedmiller, M., Trost, F.: A Case Study on Improving Defense Behavior in Soccer Simulation 2D: The NeuroHassle Approach, Springer, Berlin, Heidelberg, Iocchi L., Matsubara H., Weitzenfeld A., Zhou C. (eds) RoboCup 2008: Robot Soccer World Cup XII. RoboCup 2008. Lecture Notes in Computer Science, vol 5399., 2009. https://doi.org/10.1007/978-3642-02921-9_6

[24] Maleki, K., Valipour, M. H., Mokari, S., Ashrafi, R., Reza Jamali M., Lucas, C.: A simple method for decision making in RoboCup soccer simulation 3D environment, arXiv, arXiv:1212.1570, 2012.

[25] Riedmiller, M., Gabel, T., Hafner, R.: Reinforcement learning for robot soccer, Autonomous Robots, Volume 27, Issue 1, Springer US, 2009, pp. 55-73. https://doi.org/10.1007/s10514009-9120-4

[26] Vincze, D., Kovács, Sz., Niitsuma, M., Hashimoto, H., Korondi, P., Gácsi, M., Miklósi, Á.: Ethologically inspired human-robot interaction interfaces, In Proceedings of the 2012 Joint International Conference on Human-Centered Computer Environments, 2012, pp. 51-57. https://doi.org/10.1145/2160749.2160761

[27] Vincze, D., Kovács, Sz.: Fuzzy Rule Interpolation-based Q-learning, SACI 2009, 5th International Symposium on Applied Computational Intelligence and Informatics, Timisoara, Romania, May 28-29, 2009, ISBN: 978-1-4244-4478-6, pp. 55-59, https://doi.org/10.1109/SACI.2009.5136311 
[28] Vincze, D., Kovács, Sz.: Incremental rule base creation with Fuzzy Rule Interpolation-based QLearning, Computational Intelligence in Engineering, Studies in Computational Intelligence, Vol. 313/2010, Springer-Verlag, Berlin Heidelberg, pp. 191-203, 2010. https://doi.org/10.1007/978-3-642-15220-7_16

[29] Vincze, D.: Fuzzy Rule Interpolation and Reinforcement Learning, Proceedings of the 15th International Symposium on Applied Machine Intelligence and Informatics (SAMI 2017), Herl'any, Slovakia, pp. 173-178. https://doi.org/10.1109/SAMI.2017.7880298

[30] Vincze, D., Kovács Sz.: Rule-Base Reduction in Fuzzy Rule Interpolation-Based Q-Learning, Recent Innovations in Mechatronics (RIiM), Vol. 2. No. 1-2. 2015. https://doi.org/10.17667/riim.2015.1-2/10

[31] Vincze, D.: Automatikus tudáskinyerés fuzzy szabály interpoláció alapú Q-tanulással, Multidiszciplináris tudományok, 4. kötet. 1. sz., 2014, pp. 135-146. 